WHC-EP-0835

UC-630

\title{
Statement of Work for Services Provided by the Waste Sampling and Characterization Facility for Effluent Monitoring
}

\author{
B. P. Gleckler
}

Date Published

February 1995

DISCLAIMER

This report was prepared as an account of work sponsored by an agency of the United States Government. Neither the United States Government nor any agency thereof, nor any of their employees, makes any warranty, express or implied, or assumes any legal liability or responsibility for the accuracy, completeness, or usefulness of any information, apparatus, product, or process disclosed, or represents that its use would not infringe privately owned rights. Reference herein to any specific commercial product, process, or service by trade name, trademark, manufacturer, or otherwise does not necessarily constitute or imply its endorsement, recommendation, or favoring by the United States Government or any agency thereof. The views and opinions of authors expressed herein do not necessarily state or reflect those of the United States Government or any agency thereof.

Prepared for the U.S. Department of Energy

Office of Environmental Restoration and

Waste Management

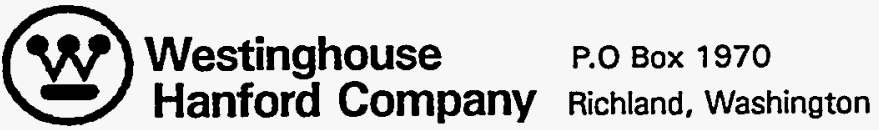

Hanford Operations and Engineering Contractor for the

U.S. Department of Energy under Contract DE-ACO6-87RL10930

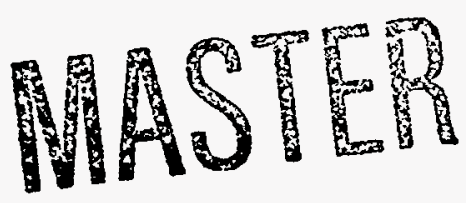

Approved for Public Release

DISTRIBUTION OF THIS DOCUMENT IS UNLIMIT:C. 


\section{DISCLAIMER}

Portions of this document may be illegible in electronic image products. Images are produced from the best available original document. 


\section{RELEASE AUTHORIZATION}

Document Number: WHC-EP-0835

$\begin{array}{ll}\text { Document Title: } & \begin{array}{l}\text { Statement of Work for Servijes Provided by the Waste } \\ \text { Sampling and Characterization Facility for Effluent } \\ \text { Monitoring }\end{array}\end{array}$

Release Date: $2 / 2 / 95$

This document was reviewed following the procedures described in WHC-CM-3-4 and is:

APPROVED FOR PUBLIC RELEASE

WHC Information Release Administration Specialist:

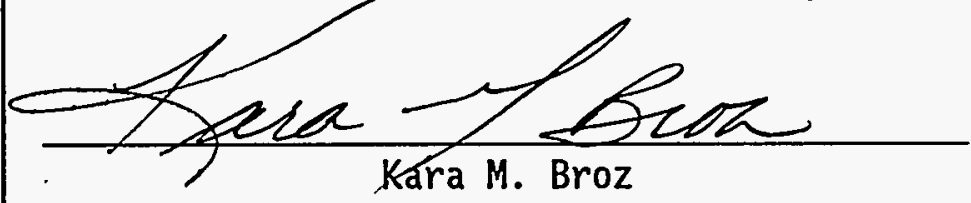

February 2, 1995 
Document Title: STATEMENT OF WORK FOR SERVICES PROVIDED BY THE WASTE SAMPLING AND CHARACTERIZATION FACILITY FOR EFFLUENT MONITORING

Prepared by:

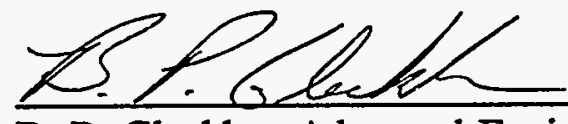

B. P. Gleckler, Advanced Engineer

Effluent Monitoring

Approved by:

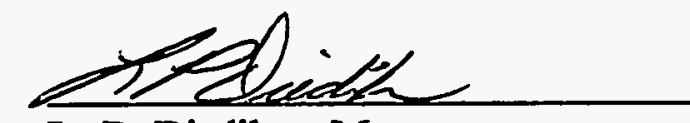

L. P. Diediker, Manager

Effluent Monitoring

Approved by:

\section{$\frac{1 / 19 / 95}{\text { Date }}$}

$\frac{1-19-95}{\text { Date }}$
Approved by: Assu Kumar Aen hr

A. K. Dasgupta, Manager

Low-Level Labs Radioanalytical Chemistry
$01 / 24 / 95$

Date

Reviewed by: Collandiphxble

R. R. Grabbe, Manager

$\frac{1-24-95}{\text { Date }}$

Low-Levels Labs

Reviewed by: K.w. Uance for

$1-25-95$

D. D. Volkman, Manager

Date

Environmental Management Systems Integration

Reviewed by:
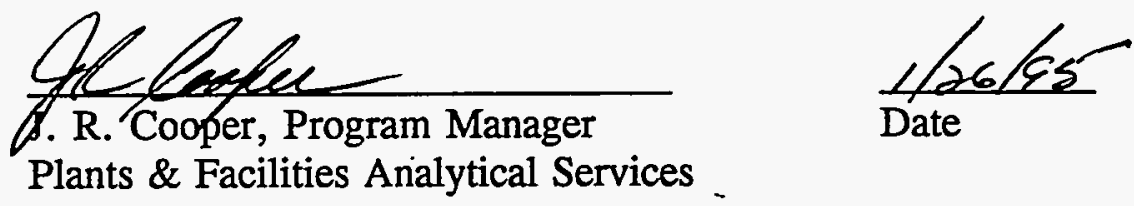

Date 
WHC-EP-0835

CONTENTS

1.0 SCOPE OF SERVICES $\ldots \ldots \ldots \ldots \ldots \ldots \ldots \ldots \ldots \ldots$

2.0 REGULATORY REPORTING REQUIREMENTS . . . . . . . . . . . . . . . . . 1

2.1 Radionuclide Air Emissions Report for Clean Air Act of 1977 . . . . . . . . . 1

2.2 Environmental Releases Report ... . . . . . . . . . . . . . . . . . . . . . . . .

2.3 Hanford Site Environmental Report . . . . . . . . . . . . . . . 2

2.4 Effluent Information System-Onsite Discharge

Information System Report ...................... 2

2.5 Near-Facility Operational Environmental Monitoring Report . . . . . . . . . 2

3.0 WSCF SERVICES AND DATA QUALITY OBJECTIVES . . . . . . . . . . . . 2

3.1 Sample and Analysis Requirements ................... 2

3.2 Composite Sample Requirements . . . . . . . . . . . . . . . . . . . . . . . . . . . . .

3.3 Year-End Data Reporting Due Dates ... . . . . . . . . . . . . . 3

3.4 Laboratory Procedures . . . . . . . . . . . . . . . . . . 3

3.5 Completeness of Analytical Data ................... 4

3.6 Quality Control ............................ 4

3.7 Access to Raw Data . . . . . . . . . . . . . . . . . . 4

3.8 Counting Error $\ldots \ldots \ldots \ldots \ldots \ldots \ldots \ldots \ldots \ldots \ldots$

3.9 Routine Electronic Transmittal of Analytical Data . . . . . . . . . . . 4

3.10 Archiving of Samples ...................... 5

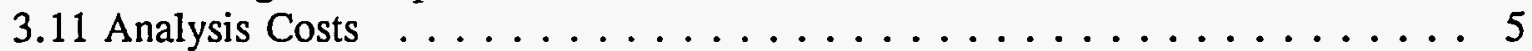

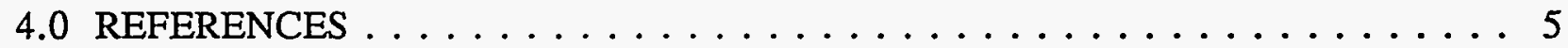

\section{GLOSSARY}

APPENDIX

DISTRIBUTION 


\section{LIST OF TABLES}

1 Ambient and Effluent Air Sample Analysis Criteria for WSCF . . . . . . . . 7

2 Groundwater Monitoring and Liquid Effluent Sample Analysis Criteria for WSCF . . . . . . . . . . . . . . . . . 8

3 Pond Vegetation and Sediment Sample Analysis Criteria for WSCF . . . . . . . . 9

4 Nonroutine Environmental Sample Analysis Criteria for WESF . . . . . . . . . 10 
WHC-EP-0835

\section{SERVICES PROVIDED BY THE WSCF FOR EFFLUENT MONITORING}

\subsection{SCOPE OF SERVICES}

This document defines the services the Waste Sampling \& Characterization Facility (WSCF) shall provide Effluent Monitoring (EM) throughout the calendar year for analysis. The internal memo contained in Appendix A identifies the samples EM plans to submit for analysis in CY-1995. Analysis of effluent (liquid and air discharges) and environmental (air, liquid, animal, and vegetative) samples is required using standard laboratory procedures, in accordance with regulatory and control requirements cited in Quality Assurance Program Plan for Radionuclide Airborne Emissions Monitoring (especially Appendix G) (WHC 1993), Quality Assurance Project Plan for Facility Effluent Monitoring Plan Activities (WHC 1994), and Operational Environmental Monitoring Program Quality Assurance Project Plan (WHC 1992a), Hanford Analytical Services Quality Assurance Plan (DOE 1994). Should changes to this document be necessary, WSCF or EM may amend it at any time with a jointly approved internal memo.

\subsection{REGULATORY REPORTING REQUIREMENTS}

It is essential for the WSCF to meet the due dates specified. The analytical data required by those due dates are necessary to maintain compliance with environmental release reporting commitments mandated by regulatory agencies and the U.S. Department of Energy (DOE). Variances to technical criteria or due dates in this document must be documented by the WSCF and approved or acknowledged by EM.

\subsection{Radionuclide Air Emissions Report for the Clean Air Act of 1977}

This report documents radionuclide air emissions from the Hanford Site and the resulting effective dose equivalent to any member of the public from those emissions. This report complies with the reporting requirements of the Code of Federal Regulations, Title 40, "Protection of the Environment," Part 61, "National Emissions Standards for Hazardous Air Pollutants," Subpart H, "National Emission Standards for Emissions of Radionuclides Other Than Radon From Department of Energy Facilities." 


\subsection{Environmental Releases Report}

The purpose of this report is to fulfill the effluent discharge reporting requirements of DOE Order 5400.1 (DOE 1988) and to summarize the compliance status of effluent releases from Westinghouse Hanford Company (Westinghouse Hanford) facilities with respect to the administrative control value guidelines given in WHC-CM-7-5, Environmental Compliance.

\subsection{Hanford Site Environmental Report}

Pacific Northwest Laboratory annually compiles and publishes this report for DOE, in compliance with DOE Order 5400.1 (DOE 1988).

\subsection{Effluent Information System-Onsite Discharge Information System Report}

Each year Westinghouse Hanford transmits this report electronically to Idaho National Engineering Laboratory in Idaho Falls for inclusion in the Effluent Information System/Onsite Discharge Information System (EIS/ODIS) database, in compliance with DOE Order 5484.1 (DOE 1983).

\subsection{Near-Facility Operational Environmental Monitoring Report}

Westinghouse Hanford publishes this report annually. The report provides a yearly summary of sampling and analysis of soil, vegetation, ambient air, etc. near Westinghouse Hanford facilities.

\subsection{WSCF SERVICES AND DATA QUALITY OBJECTIVES}

WSCF shall provide the following analytical services when analyzing low-level environmental and effluent samples from EM.

\subsection{Sample and Analysis Requirements}

All services necessary shall be provided to complete the analytical requirements listed in Tables 1 through 4. Analyses shall be performed in accordance with applicable requirements and procedures contained in the references listed in section 1.0 above. Analytical results shall be expressed in the units shown for the respective minimum 
detectable concentrations (MDC) in the tables. (By September 30th of each year, EM will provide updated analytical requirements to WSCF that identify the analytes to be measured in samples from the various effluent streams, Appendix A for CY-1995 information.)

\subsection{Composite Sample Requirements}

Air emission composite samples for the first three quarters shall be reported to EM within the second month following the end of the sampling quarter. All monthly liquid samples shall be reported to EM within 45 days after the end of the sampling month.

\subsection{Year-End Data Reporting Due Dates}

The due dates for submission of year-end analysis results to EM on weekly samples collected up through December 31st are: (Note these dates currently apply to 222-S.)

- Air emission data . . . . . . . . . . . . . . . . February 17, 1996

- Liquid effluent data . . . . . . . . . . . . . . . . . . . . February 24, 1996

- Environmental data (pond vegetation and sediment) . . . . . March 17, 1996

The analysis results from any weekly sample collected on or after January 1st of the succeeding new year will be applied to that year.

\subsection{Laboratory Procedures}

Use laboratory analytical procedures that are:

- In compliance with EPA Method 114, Section 4.0, "Quality Assurance Methods, " 40 CFR Part 61, Appendix B (specifically, 4.4 and 4.5), and applicable requirements and procedures contained in the references listed in Section 1.0 above.

- In compliance with Chapter 6.0 of the "Environmental Regulatory Guide for Radiological Effluent Monitoring and Environmental Surveillance" document (DOE 1991).

- Appropriate to the sample medium and size and the analysis requirements listed in Tables 1 through 4. 


\subsection{Completeness of Analytical Data}

Completeness of analytical data such that:

- WSCF produces a minimum of $90 \%$ usable analytical data, for all EM-related samples received.

\subsection{Quality Control}

WSCF shall participate in the U.S. DOE Environmental Measurements Laboratory (EML) inter-comparison program, as required per DOE 1991. WSCF shall participate in all U.S. EPA laboratory inter-comparison programs, applicable to the analyses being performed. Quality control (QC) test results shall be provided quarterly. EML and EPA laboratory inter-comparison results shall be provided annually.

The QC tests shall be for accuracy, precision, completeness (see section 3.5 above), and background. Accuracy shall be within $\pm 25 \%$ at the $95 \%$ confidence interval, WHC 1992a. All tests shall be in accordance with applicable requirements and procedures contained in the references listed in Section 4.0. EM will provide a minimum sample volume of $4 \mathrm{~L}$ for the performance of radiological quality control tests.

\subsection{Access to Raw Data}

As needed, EM shall have access to all available raw data related to EM samples. WSCF shall provide analysis printouts upon request (i.e. GEA list of peaks identified data).

\subsection{Counting Error \& Minimum Detectable Concentration}

Provide the counting error associated with each analytical result.

WSCF shall ensure that the sample's MDC does not exceed the values specified in Tables 1 through 3 when the nominal sample volume is provided. WSCF will not be accountable for maintaining the MDC limits when samples less than the nominal sample volume are provided. When sample sizes are less than or greater than the nominal volumes specified in Tables 1 through 3, EM may adjust the MDCs for samples by multiplying the specified MDC by the ratio of the actual sample size and the nominal sample size.

\subsection{Routine Electronic Transfer of Analytical Data}

Routinely and electronically transmit analytical data to EM. WSCF shall electronically transmit all calendar-year 1995 data to EM by February 24, 1996. 


\subsection{Archiving of Samples}

Ambient air monitoring samples shall be archived upon the completion of the total $\alpha$ and $\beta$ analysis. Archived ambient air samples will collected bi-annually by the Site Surveillance Radiological Control Organization. These samples can be identified as the samples with the Nxxx series EDP codes.

Effluent air samples, samples received in white air sample envelopes with EDP Code listed in the Appendix, shall be archived until composited for quarterly analyses.

Backup record and effluent CAM air samples shall not be analyzed but shall be archived until June 30, 1996. These samples can be identified as the samples received in white envelopes stamped "Archive Only", which are not listed in the Appendix.

\subsection{Analysis Costs}

The sample analysis costs provided in Tables 1 through 3 are estimated and may fluctuate due to changes in prices and workscope. Adjustments made to sample analysis costs shall have the concurrence of EM.

\subsection{REFERENCES}

Clean Air Act of 1977, 42 USC 7401 et seq.

DOE, 1988, General Environmental Protection Program, DOE Order 5400.1, U.S. Department of Energy, Washington, D.C.

DOE, 1983, Environmental Protection, Safety and Health Protection Information Reporting Requirements, DOE Order 5484.1, U.S. Department of Energy, Washington D.C.

DOE, 1991, Environmental Regulatory Guide for Radiological Effluent monitoring and Environmental Surveillance, DOE/EH-0173T, U.S. Department of Energy, Washington D.C.

DOE, 1994, Hanford Analytical Services Quality Assurance Plan, DOE/RL-94-55 Revision 0, U.S. Department of Energy, Richland, Washington.

40 CFR 61, "National Emissions Standards for Hazardous Air Pollutants," Title 40, Code of Federal Regulations, Part 61, as amended, U.S. Environmental Protection Agency, Washington, D.C. 
40 CFR 61, "Quality Assurance Methods," Title 40, Code of Federal Regulations, Part 61, as amended, Appendix B, U.S. Environmental Protection Agency, Washington, D.C.

WHC-CM-7-5, Environmental Compliance, Westinghouse Hanford Company, Richland, Washington.

WHC, 1993, Quality Assurance Program Plan for Radionuclide Airborne Emissions Monitoring, WHC-EP-0536 Revision 1, Westinghouse Hanford Company, Richland, Washington.

WHC, 1992a, Operational Environmental Monitoring Program Quality Assurance Project Plan, WHC-EP-0538 Revision 1, Westinghouse Hanford Company, Richland, Washington.

WHC, 1992b, Quality Assurance Project Plan for Facility Effluent Monitoring Plan Activities, WHC-EP-0446 Revision 1, Westinghouse Hanford Company, Richland, Washington.

WHC, 1994a, Quality Assurance Project Plan for Facility Effluent Monitoring Plan Activities, WHC-EP-0446 Revision 2, Westinghouse Hanford Company, Richland, Washington.

WHC, 1994b, Quality Assurance Project Plan for Radioactive Airborne Emissions Data Compilation and Reporting, WHC-EP-0528 Revision 1, Westinghouse Hanford Company, Richland, Washington.

WHC, 1994c, Quality Assurance Program Plan for Radionuclide Airborne Emissions Monitoring, WHC-EP-0536 Revision 1, Westinghouse Hanford Company, Richland, Washington. 
Table 1. Ambient and Effluent Air

Sample Analysis Criteria for WSCF

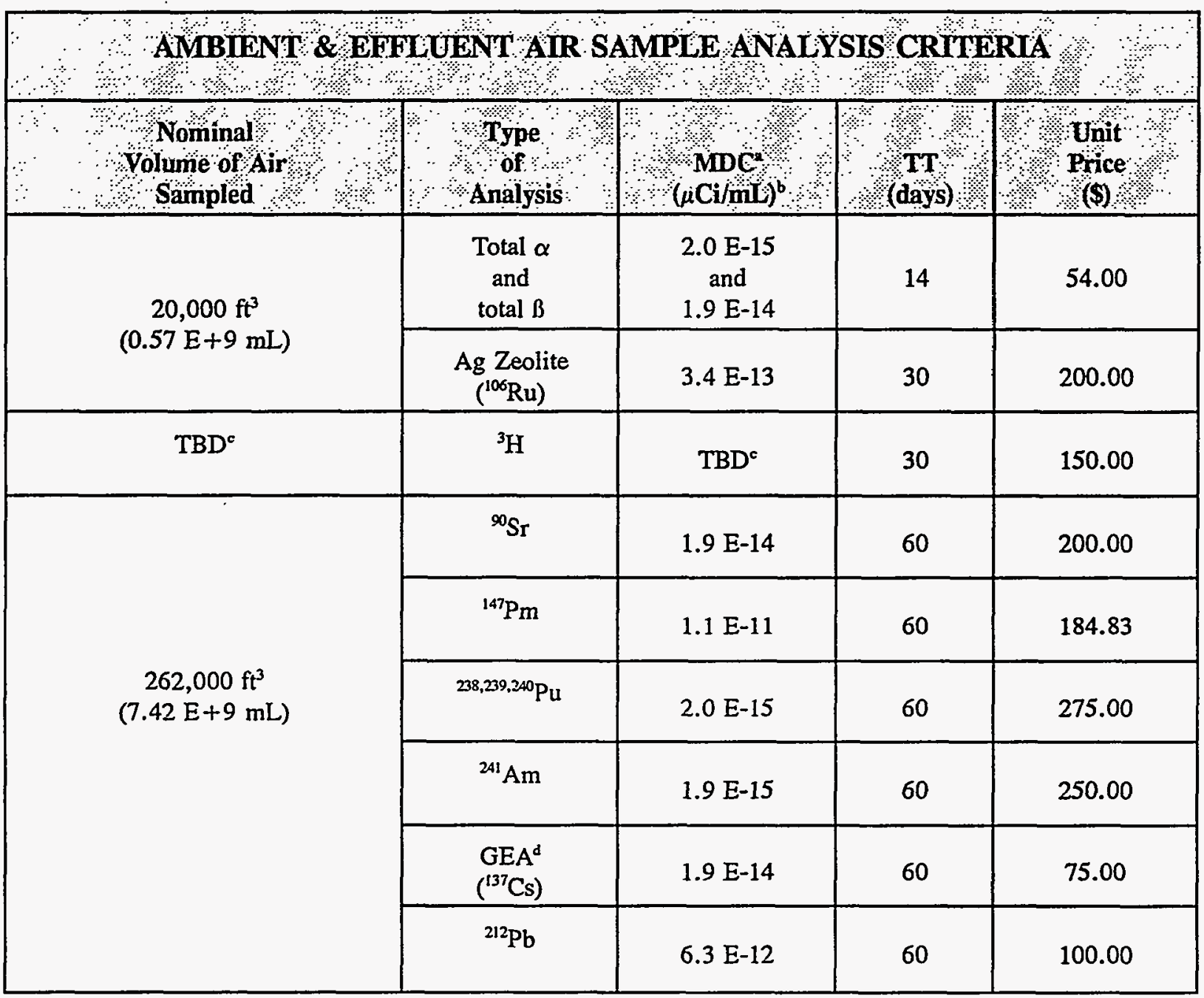

MDC = Minimum Detectable Concentration

$\mathrm{TT}=$ Turnaround Time

$\mathrm{TBD}=$ To Be Determined

a MDC's shall be as low as reasonably attainable, but shall not exceed the values specified in the table. MDC values obtained from 40 CFR 61 Appendix E Table II.

b Unless other units of measure are indicated.

c To be determined upon selection of a sampling method.

d All positive GEA results shall be reported, with the exception of the short-lived ${ }^{22} \mathrm{Rn}$ and ${ }^{20} \mathrm{Rn}$ progeny. 
Table 2. Groundwater Monitoring and Liquid Effluent Sample Analysis Criteria for WSCF ${ }^{2}$

\begin{tabular}{|c|c|c|c|c|}
\hline GROUNDWAT & ERMONITOR MN & $\begin{array}{l}\text { \& UIQUID } \\
\text { CRITERIA }\end{array}$ & UENTSAMP & CEANALYSIS \\
\hline Samplesize & $\begin{array}{ccc} & \text { Type } \\
\text { yof } & \\
\text { Analysis } & \\
\end{array}$ & $\begin{array}{l}\text { Mm } \\
(\mu \mathrm{Ci} / \mathbf{m L})^{\mathrm{b}}\end{array}$ & 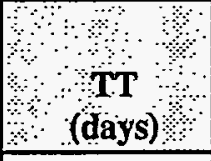 & $\begin{array}{l}\text { Unit } \\
\text { Price } \\
\text { (\$) }\end{array}$ \\
\hline \multirow{11}{*}{$1.0 \mathrm{~L}$} & $\begin{array}{c}\text { Total } \alpha \\
\text { and } \\
\text { total } \beta\end{array}$ & $\begin{array}{c}1.2 \mathrm{E}-09 \\
\text { and } \\
4.0 \mathrm{E}-08\end{array}$ & 30 & 110.90 \\
\hline & ${ }^{90} \mathrm{Sr}$ & $4.0 \mathrm{E}-08$ & 30 & 200.00 \\
\hline & $\begin{array}{l}\mathrm{GEA}^{\mathrm{d}} \\
\left({ }^{137} \mathrm{Cs}\right)\end{array}$ & $1.2 \mathrm{E}-07$ & 30 & 100.00 \\
\hline & Total Ue & $\begin{array}{l}7.2 \mathrm{E}-08 \\
\mathrm{~g} \mathrm{U} / \mathrm{mL}\end{array}$ & 30 & 150.00 \\
\hline & ${ }^{238,235,234} U^{e}$ & $2.0 \mathrm{E}-08$ & 30 & TBD \\
\hline & ${ }^{3} \mathrm{H}$ & 8.0 E-05 & 30 & 150.00 \\
\hline & ${ }^{99} \mathrm{Tc}$ & 4.0 E-06 & 30 & 100.00 \\
\hline & ${ }^{241} \mathrm{Am}$ & 1.2 E-09 & 30 & 250.00 \\
\hline & $238,239,240 \mathrm{Pu}$ & $1.2 \mathrm{E}-09$ & 30 & 300.00 \\
\hline & $\mathrm{pH}$ & NA & 60 & 58.73 \\
\hline & $\mathrm{NO}_{3}$ & $\begin{array}{c}1.0 \mathrm{E}-06 \\
\mathrm{~g} / \mathrm{mL}\end{array}$ & 60 & 46.52 \\
\hline
\end{tabular}

MDC = Minimum Detectable Concentration

$\mathrm{TT}=$ Turnaround Time

$\mathrm{TDB}=$ To Be Determined.

${ }^{a}$ Liquid effluent samples shall be analyzed unfiltered, where as ground water samples shall be filtered and only the filtrate analyzed. The EDP codes for the liquid effluent samples are identified in memo 88420-94-130's Attachment.

${ }^{b}$ MDC's shall be as low as reasonably attainable, but shall not exceed the values specified in the table. MDC values obtained from $4 \%$ of the Derived Concentration Guidelines (DCG).

c Unless other units of measure are indicated.

${ }^{d}$ All positive GEA results shall be reported, with the exception of the short-lived ${ }^{222} \mathrm{Rn}$ and ${ }^{220} \mathrm{Rn}$ progeny.

e Total uranium analyses will be performed until an isotopic uranium analysis is established. 
Table 3. Pond Vegetation and Sediment Sample Analysis Criteria for WSCF

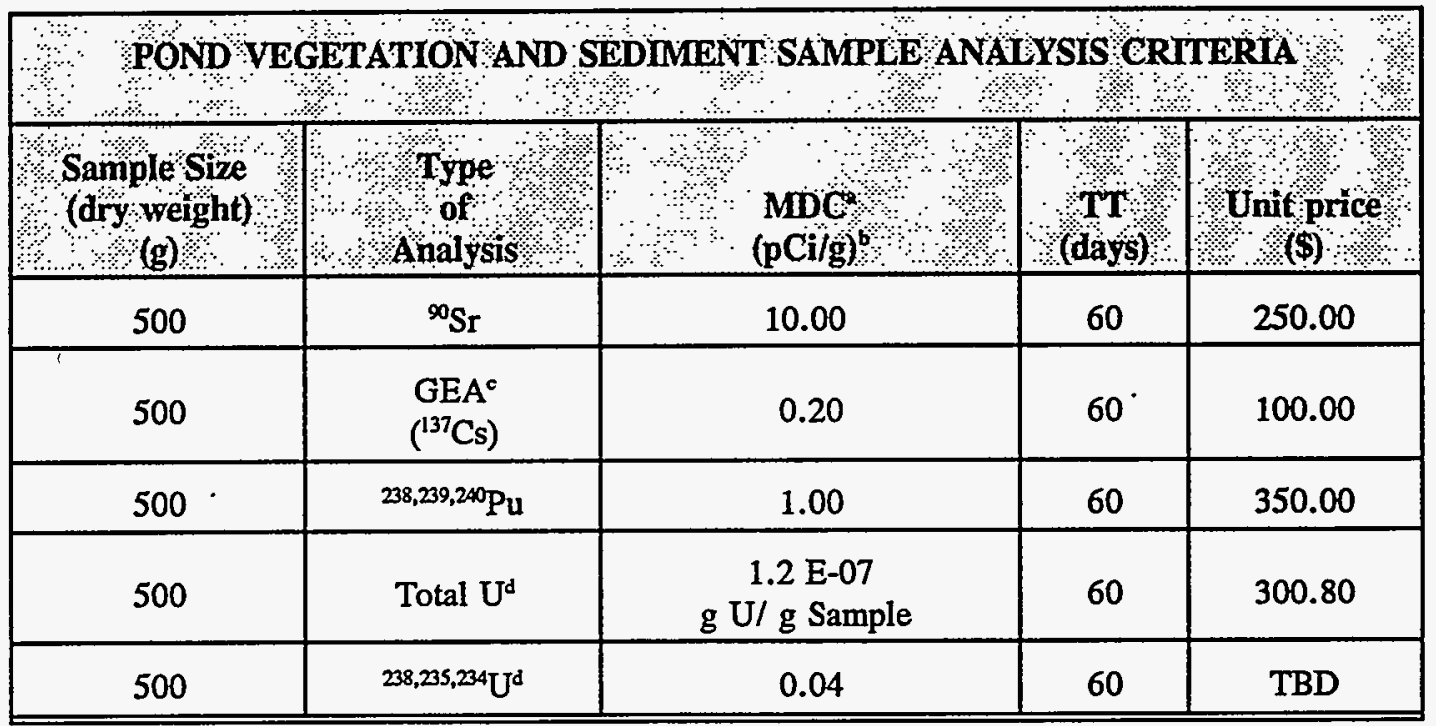

MDC = Minimum Detectable Concentration

TT = Turnaround Time

a MDC's shall be as low as reasonably attainable, but shall not exceed the values specified in the table.

Unless other units of measure are indicated

c All positive GEA results shall be reported, with the exception of the short-lived ${ }^{2 m} \mathrm{Rn}$ and ${ }^{20} \mathrm{Rn}$ progeny.

dotal uranium analyses will be performed until an isotopic uranium analysis is established. 


\section{Table 4. Non-Routine Environmental Samples, Sample Analysis Criteria for WSCF}

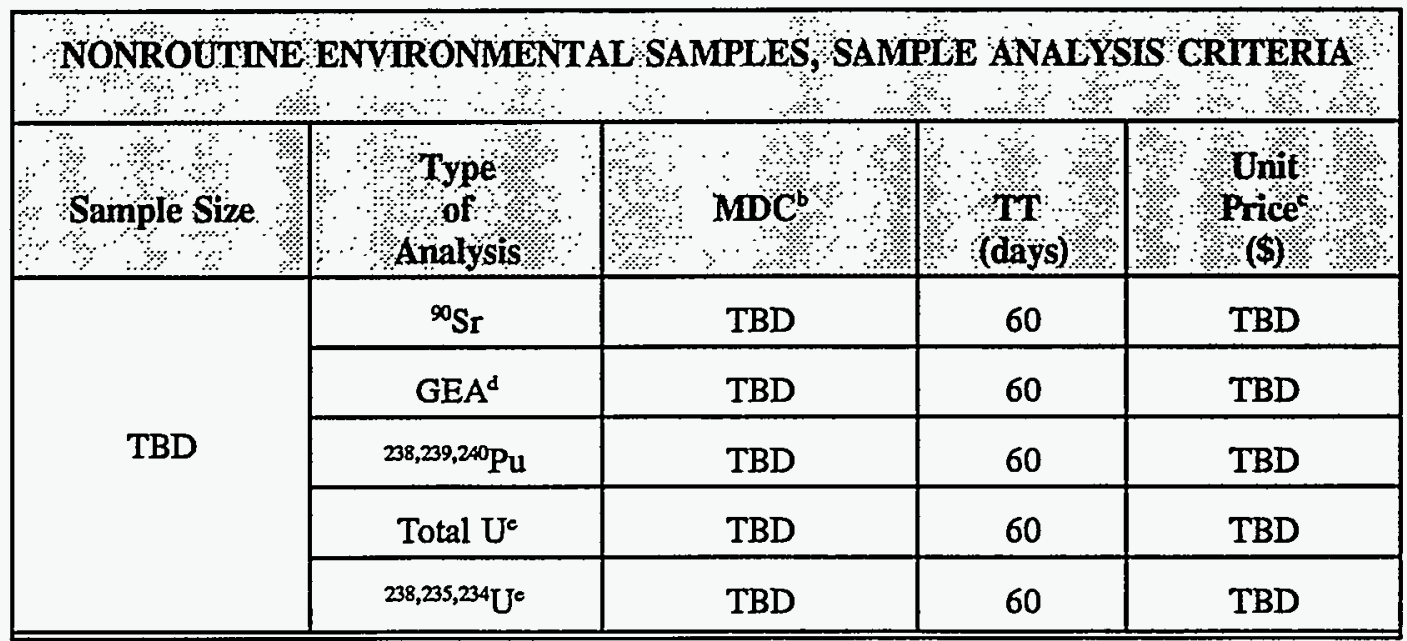

MDC $=$ Minimum Detectable Concentration

$\mathrm{TT}=$ Turnaround Time

TBD $=$ To Be Determined

a Occasional nonroutine air, liquid, vegetation, and sediment samples may need analysis. WSCF can not accept the following types of nonroutine samples: animals, feces, nests, samples with an exposure rate $>1 \mathrm{mR} / \mathrm{h}$, and/or samples containing $>10$ nCi of any alpha emitter.

${ }^{b}$ MDC values and units for nonroutine samples shall be dependent on sample type and commensurate with the values listed in Tables 1 through 3. MDC's shall be as low as reasonably attainable, but shall not exceed the values specified in the Tables 1 through 3.

${ }^{c}$ Cost for nonroutine samples shall be dependent on sample type and commensurate with the values listed in Tables 1 through 3.

A All positive GEA results shall be reported, with the exception of the short-lived ${ }^{222} \mathrm{Rn}$ and ${ }^{200} \mathrm{Rn}$ progeny.

c Total uranium analyses will be performed until an isotopic uranium analysis is established. 


\section{GLOSSARY}

\section{ACRONYMS}

$\begin{array}{ll}\text { DOE } & \text { U.S. Department of Energy } \\ \text { EIS-ODIS } & \text { Effuent Information System-Onsite Discharge Information System } \\ \text { EM } & \text { Effluent Monitoring } \\ \text { EPA } & \text { U.S. Environmental Protection Agency } \\ \text { MDC } & \text { Minimum Detectable Concentration } \\ \text { TT } & \text { Turnaround Time } \\ \text { TBD } & \text { To Be Determined } \\ \text { WHC } & \text { Westinghouse Hanford Company }\end{array}$

\section{DEFINITION OF TERMS}

Accuracy. The degree of agreement of a measurement with a true or known value.

Completeness. A measure of the amount of valid data obtained compared to the amount expected under normal conditions.

Precision. A measure of the agreement among individual measurements of the same parameters under similar conditions.

Turnaround time. Elapsed time, in days, from when a sample is received by the laboratory until the analysis results are reported to EM for that sample. 


\title{
WHC-EP-0835
}

\begin{abstract}
APPENDIX
Analytical Requirements for Effluent Sampling CY 1995

(Tables supersede those contained in Memo 88420-94-130)
\end{abstract}

APP-1 


\section{Air Emissions \\ CY-1995 Sample Analyses per Year \\ (Performed by WSCF)}

\begin{tabular}{|c|c|c|c|c|c|c|c|c|c|c|c|c|}
\hline$\therefore$ Faclity & \%EDP $\%$ & \%stackló & \% & $\because \because 3$ & an & a $\cdots \cdots$ & OAlalyst & s & $\therefore \because$ & un & : & 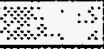 \\
\hline \%k\% & \%codos & Núnoer & alphodofolat & EEA & $\mathrm{sin}-90$ & $\mathrm{P}_{\mathrm{m}-147}$ & pư $=238$ & Pú-239/240 & Am-24t & Fitum & PQtatal & स्थ $z$ \\
\hline PLFEX & $\begin{array}{l}A 552 \\
A 568 \\
A 511 \\
A 540 \\
A 542 \\
A 543 \\
A 545 \\
A 546 \\
A 547 \\
A 548 \\
A 549 \\
A 550 \\
A 544\end{array}$ & $\begin{array}{l}291-A-1 \\
296-A-1 \\
296-A-2 \\
296-A-3 \\
296-A-5 A \\
296-A-5 B \\
296-A-6 \\
296-A-7 \\
296-A-8 \\
296-A-10 \\
296-A-14\end{array}$ & $\begin{array}{r}28 \\
28 \\
4 \\
4 \\
4 \\
4 \\
4 \\
4 \\
4 \\
4 \\
4\end{array}$ & 4 & 41 & 4 & 4 & 4 & 4 & & 12 & 26 \\
\hline B-Plant & $\begin{array}{l}B 691 \\
8686 \\
B 748 \\
8690\end{array}$ & $\begin{array}{l}291-B-1 \\
296-B-5 \\
296-B-10 \\
296-B-13\end{array}$ & \begin{tabular}{r|}
28 \\
4 \\
28 \\
4
\end{tabular} & 4 & 4 & & & 4 & 4 & & & \\
\hline $\begin{array}{c}\text { East } \\
\text { Tank } \\
\text { Farms }\end{array}$ & \begin{tabular}{|c|}
$E 058$ \\
$E 052$ \\
$E 059$ \\
E0268 E027 \\
$E 060$ \\
$E 061$ \\
$E 197$ \\
$E 645$ \\
$E 643$ \\
$E 0018$ E002 \\
$E 080$ \\
$E 297$ \\
$E 270$ \\
$E 9338 E 934$ \\
$E 272$ \\
$E 901$ \\
$E 903$ \\
$E 013$ \\
$E 028 \&$ E029 \\
$E 015$ \\
$E 886$ \\
$E 069$ \\
$E 068$ \\
$E 120$ \\
$E 209$ \\
$E 301-399 * *$ \\
\end{tabular} & $\begin{array}{l}296-A-12 \\
296-A-13 \\
296-A-17 \\
296-A-18 \\
296-A-19 \\
296-A-20 \\
296-A-21 \\
296-A-22 \\
296-A-25 \\
296-A-26 \\
296-A-27 \\
296-A-28 \\
296-A-29 \\
296-A-30 \\
296-A-40 \\
296-A-41 \\
296-B-28 \\
296-C-5 \\
296-P-16 \\
296-P-17 \\
296-P-31 \\
296-P-32 \\
\end{array}$ & \begin{tabular}{l|}
26 \\
26 \\
28 \\
26 \\
26 \\
28 \\
26 \\
26 \\
26 \\
26 \\
26 \\
26 \\
26 \\
26 \\
26 \\
26 \\
26 \\
26 \\
28 \\
26 \\
26 \\
13 \\
\end{tabular} & $\begin{array}{l}4 \\
4 \\
4\end{array}$ & $\begin{array}{l}4 \\
4 \\
4 \\
4 \\
4 \\
4 \\
4 \\
4 \\
4 \\
4\end{array}$ & & & $\begin{array}{l}4 \\
4 \\
4\end{array}$ & $\begin{array}{l}4 \\
4 \\
4\end{array}$ & $\begin{array}{l}4 \\
4\end{array}$ & & $\begin{array}{l}52 \\
52 \\
52 \\
52\end{array}$ \\
\hline $\begin{array}{c}222-S \\
\mathrm{Lab}\end{array}$ & $\begin{array}{l}\text { S264 } \\
\text { S289 }\end{array}$ & $\begin{array}{l}296-S-16 \\
296-5-21\end{array}$ & $\begin{array}{l}26 \\
26 \\
\end{array}$ & & & & & 4 & 4 & & & \\
\hline $\begin{array}{c}\text { S-Plant } \\
\& \\
\text { U-Plant }\end{array}$ & $\begin{array}{l}\text { So06 } \\
\text { S032 } \\
\text { S008 } \\
\text { So04 } \\
\text { S016 } \\
\text { U771 }\end{array}$ & $\begin{array}{l}291-S-1 \\
296-S-2 \\
296-S-4 \\
296-S-6 \\
296-S-7 W \\
291-U-1\end{array}$ & \begin{tabular}{r|}
4 \\
4 \\
4 \\
4 \\
.26 \\
4
\end{tabular} & & & & & & & & & \\
\hline $\begin{array}{c}\text { T-Plant } \\
\& \\
\text { TRUSAF }\end{array}$ & $\begin{array}{l}T 785 \\
T 788 \\
T 783 \\
T 784\end{array}$ & $\begin{array}{l}291-T-1 \\
296-T-13 \\
296-T-11 \\
296-T-12\end{array}$ & \begin{tabular}{l|}
26 \\
28 \\
26 \\
28
\end{tabular} & 4 & 4 & & & 4 & 4 & & & \\
\hline $\begin{array}{l}\text { West } \\
\text { Tank } \\
\text { Farms }\end{array}$ & \begin{tabular}{|c|}
$W 191$ \\
$W 190$ \\
$W 195$ \\
$W 301-390$ \\
$W 111$ \\
W096 \\
W880 \\
W117 \\
W882 \\
W884
\end{tabular} & $\begin{array}{l}296-P-22 \\
296-P-23 \\
296-P-28 \\
296-P-32 \\
296-S-15 \\
296-S-18 \\
296-S-22 \\
296-T-17 \\
296-T-18 \\
296-U-11\end{array}$ & \begin{tabular}{r|}
26 \\
22 \\
4 \\
13 \\
26 \\
26 \\
26 \\
26 \\
26 \\
26 \\
\end{tabular} & $\begin{array}{l}4 \\
4 \\
4 \\
4\end{array}$ & $\begin{array}{l}4 \\
4 \\
4 \\
4 \\
4 \\
4 \\
4\end{array}$ & & & $\begin{array}{l}4 \\
4 \\
4 \\
4\end{array}$ & $\begin{array}{l}4 \\
4 \\
4 \\
4\end{array}$ & & & \\
\hline Waste Comp. & Woo3 & $296-W-3$ & 26 & & & & & & & & & \\
\hline WSCF & $\begin{array}{l}\text { L110 } \\
\text { L111 }\end{array}$ & $\begin{array}{l}696-W-1 \\
696-W-2\end{array}$ & $\begin{array}{l}26 \\
26 \\
\end{array}$ & & & & & & & & & \\
\hline $\begin{array}{c}\text { Plutonium } \\
\text { Finishing } \\
\text { Plant }\end{array}$ & $\begin{array}{l}2810 \\
2813 \\
Z 913 \\
2802 \\
Z 814 \\
Z 915 \\
\end{array}$ & $\begin{array}{l}291-Z-1 \\
296-Z-3 \\
296-Z-5 \\
296-Z-6 \\
296-Z-14 \\
296-Z-15 \\
\end{array}$ & \begin{tabular}{r|}
26 \\
26 \\
26 \\
26 \\
26 \\
1
\end{tabular} & \begin{tabular}{|l}
4 \\
4
\end{tabular} & & & 4 & $\begin{array}{l}4 \\
4\end{array}$ & $\begin{array}{l}4 \\
4\end{array}$ & & & \\
\hline$\ldots \cdot \ldots$ & . & Totals & 1339| & 98 & 88 & 4 & 8 & 104 & 104 & 16 & 12 & 234 \\
\hline
\end{tabular}

- AgZ analysis includes $R u-108, \mathrm{Sn}-113, \mathrm{Sb}-125$ and $\mathrm{I}-129$.

-* Minimum GEA analysis will be for $\mathrm{Cs}-137, \mathrm{Ru}-106$, and $\mathrm{Sn}-113$. All positive GEA results shall be reported also.

*** EM will provide explicit instructions on the composited analyses of these samples. 


\section{Liquid Effluents \\ CY-1995 Sample Analyses per Year}

(Performed by WSCF)

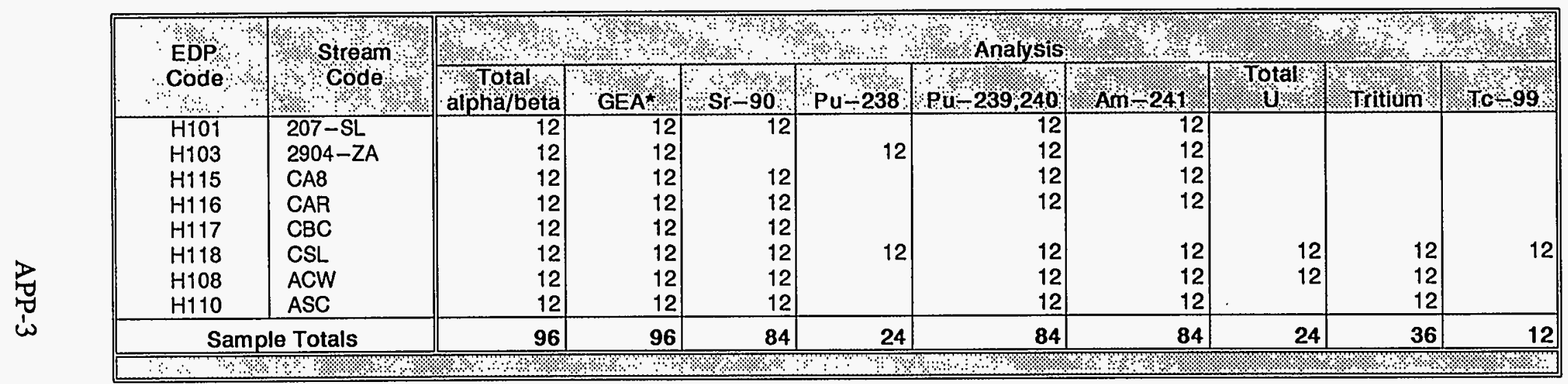

* Minimum GEA analysis will be for Cs-137, Ru-106, and Sn-113. All radionuclides with positive GEA results shall be reported also. 


\section{Near-Field Monitoring* CY-1995 Sample Analyses per Year (Performed by WSCF)}

\begin{tabular}{|c|c|c|c|c|c|c|c|c|c|}
\hline sample & W\%Aro a & & & & & \%Analys & (b) & ঋ. & א⿵冂卄 \\
\hline Modia & ४ै. & KTotohal beta & GEAN & $\% \mathrm{sr}-90$ & \%protsol & Uniso & $\mathrm{S} /$ tritium & P. & Nitrates. \\
\hline Air & $\begin{array}{l}100 \\
200 \\
300 \\
400 \\
\end{array}$ & $\begin{array}{r}208 \\
884 \\
26\end{array}$ & & & & & & & \\
\hline Samp & le Totals & 1118 & $\mathbf{0}$ & 0 & 0 & 0 & 0 & 0 & 0 \\
\hline \%ం \% & $\% \%$ & 8 & & \% & 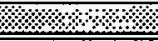 & 4 & 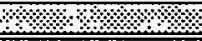 & 3 & \\
\hline Water & $\begin{array}{l}100 \\
200 \\
300 \\
400 \\
\end{array}$ & 48 & 48 & 48 & 48 & 48 & 16 & 208 & 16 \\
\hline Samp & le Totals & 48 & 48 & 48 & 48 & 48 & 16 & 208 & 16 \\
\hline \%\%\% & \%\%\% & $\%$ & . & 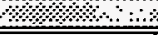 & $\% \%$ & \% & $1 \% \%$ & 1.\% & $\%$ \\
\hline $\begin{array}{l}\text { Aquatic } \\
\text { Vegitation }\end{array}$ & $\begin{array}{l}100 \\
200 \\
300 \\
400 \\
\end{array}$ & & 4 & 4 & 4 & 4 & & & \\
\hline Samp & le Totals & 0 & 4 & 4 & 4 & 4 & 0 & 0 & $\mathbf{0}$ \\
\hline $18 \%$ & $\%$ \% & & & $6,3 \%$ & \%६ & WW & $\%, 0$ & \%०र & 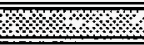 \\
\hline $\begin{array}{l}\text { Aquatic } \\
\text { Sediment }\end{array}$ & $\begin{array}{l}100 \\
200 \\
300 \\
400 \\
\end{array}$ & & 4 & 4 & 4 & 4 & & & \\
\hline Samp & le Totals & $\mathbf{0}$ & 4 & 4 & 4 & 4 & 0 & 0 & 0 \\
\hline$\therefore \ldots \ldots \%$ & \%ం\% & मिए। & $\%$ W & 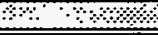 & & 3 & 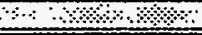 & \%०\% & $\%$ \\
\hline $\begin{array}{c}\text { Non-Routine } \\
\text { Samples }\end{array}$ & $\begin{array}{c}\text { Soil } \\
\text { Vegitation } \\
\text { Animal } \\
\end{array}$ & & $\begin{array}{l}50 \\
50 \\
50 \\
\end{array}$ & $\begin{array}{l}50 \\
50 \\
50 \\
\end{array}$ & $\begin{array}{l}50 \\
50 \\
50 \\
\end{array}$ & $\begin{array}{l}50 \\
50 \\
50 \\
\end{array}$ & & & \\
\hline Samp & le Totals & 0 & 150 & 150 & 150 & 150 & 0 & 0 & 0 \\
\hline$\therefore$ & H & 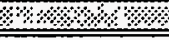 & m & 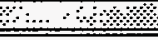 & 0 & 3 & 3 & $\ddot{*}$ & $\because$ \\
\hline
\end{tabular}

- All Near-Field Monitoring Samples are identified by the Nxox or RMxox series EDP codes. Specific EDP codes are not provided in this table since, no other samples share these EDP codes. These samples will be transproted in planchet holders, rather than air sample envelopes.

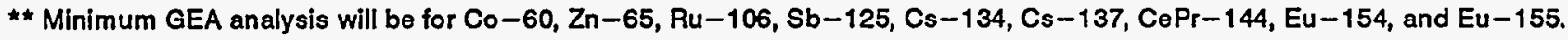
All radionuclides with positive GEA results shall be reported also. 


\section{Special Tank Farm Air Samples ${ }^{1}$ CY-1995 Sample Analyses per Year} (Performed by WSCF)

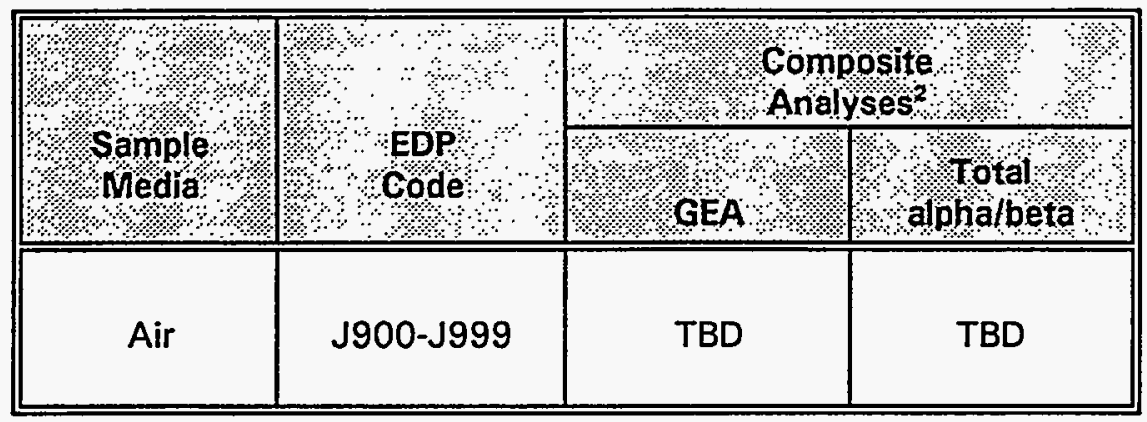

1 These workplace air samples will require analysis for Effluent Monitoring purposes. They need only be archived, until Effluent Monitoring provides explicit instructions for compositing them and analyzing them.

2 These samples shall only be analyzed unpon compositing, including total alpha and beta analysis. The GEA will be performed prior to ashing to determine cesium content. The GEA will only be utilized to determine the cesium content of the samples, which would be lost during ashing. 


\section{DISTRIBUTION}

Number of copies

ONSITE

$1 \quad$ U.S. Department of Energy-

Richland Operations Office

$\begin{array}{ll}\text { Public Reading Room A1-65 } & \text { A }\end{array}$

6 Bechtel Hanford Incorporated

R. G. Egge

T7-05

M. C. Hughes

$\mathrm{H} 4-92$

S. D. Liedle

H4-84

T. D. Miller

T7-05

M. R. Mórton

X5-55

S. R. Weil

H4-86

106 Westinghouse Hanford Company

J. E. Atterberry

T6-14

D. D. Bachand

R1-51

J. M. Barnett

T1-30

M. L. Bell

T6-16

R. J. Boom

T1-30

J. R. Cooper

H4-19

P. J. Crane

T3-28

G. M. Crummel

R1-51

A. K. Dasgupta

S3-28

W. E. Davis

H6-20

J. L. Deichman

H4-19

L. P. Diediker (45)

T1-30

J. N. Diven

B5-25

W. T. Dixon

H6-21

D. A. Dodd

T6-50

J. J. Dorian

H6-30

M. R. Dowell

S3-28

D. L. Dyekman

$\mathrm{X} 0-21$

G. E. Entrop

S6-70

P. J. Fortin

T6-12

T. P. Frazier

T1-30

B. P. Gleckler

T1-30 
R. R. Grabbe

T. G. Ibsen

K. Iwatate

S3-28

A. R. Johnson

H6-20

D.. L. Johnson

S6-17

R. E. Johnson

T1-30

S. E. Killoy

S6-70

E. J. Kosiancic

T6-16

J. G. Kristofzski

T6-06

W. D. Leggett

T6-07

P. J. Martell

T1-30

D. J. McBride

T5-54

K. M. McDonald

T4-03

A. K. McDowell

R1-51

D. L. Mitchell

H6-32

S. T. Noga

S6-19

C. J. Perkins

$\mathrm{X} 0-21$

J. K. Perry

H6-20

J. R. Prilucik

T6-24

T. M. Ridge

S6-70

J. W. Schmidt

H6-30

J. L. Spahr

S3-30

R. A. Spohr.

H4-21

P. J. Sullivan

T5-54

L. H. Taylor

T6-50

S. P. Thomas

T1-30

R. R. Thompson

H6-32

G. L. Troyer

T6-50

R. D. Weissenfels

S6-70

D. W. Wilson

S6-70

C. D. Wollam

S6-17

Central Files

L8-15

Correspondence Control

A3-01

President's Office

B3-01

OSTI (2)

L8-07

Publications Services

R1-08

EPIC

H4-22 